\title{
List of exhibits
}

1.1 Mentions of 'the economy' (modern usage) in UK winning party manifesto

2.1 The three prongs of neoclassical economics 38

2.2 Basic supply and demand graph 42

2.3 IS/LM model 44

2.4 A typical macroeconomic 'operate a model' question 49

2.5 A typical microeconomic 'operate a model' question 50

2.6 Curriculum review breakdown of assessment 52

2.7 Percentage of marks for evaluation in all London School of Economics economics modules $\quad 53$

3.1 Economic perspectives $\quad 62$

5.1 Comparative funding for full-time undergraduate study per student before and after 2010 reforms 136

A Example of an 'operate a model' question from a behavioural economics exam 176 